\title{
ADIPONECTIN CONCENTRATIONS AS A CRITERION OF METABOLIC CONTROL IN PERSONS WITH TYPE 2 DIABETES MELLITUS?
}

\author{
David Stejskal ${ }^{\mathrm{a}}$, Viktor Růžička ${ }^{\mathrm{a}}$, Sylva Adamovskáa, Renata Jurákováa \\ Jitka Proškováa ${ }^{\mathrm{a}}$ Ladislav Jedelskýa, Josef Bartek ${ }^{\mathrm{b}}$ \\ a Department of Laboratory Medicine, Hospital Šternberk, Jivavská 20, 785 16, Šternberk, Czech Republic \\ $b$ Institute of Medical Chemistry and Biochemistry, Faculty of Medicine, Palacký University Olomouc, Hněvotínská 3 , \\ 77515 Olomouc, Czech Republic
}

Received: October 25, 2003; Accepted: November 15, 2003

Key words: Adiponectin / Diabetes mellitus type 2 / Atherosclerosis / Hypertension / Obesity / Insulin Resistance

Adiponectin (ADP) is an adipocytokin with many antiatherogenic properties; its decreased level is associated with numerous atherogenic diseases and syndromes (e.g. diabetes mellitus (DM), dyslipidemia, endothelial dysfunction, hypertension, and obesity). Decreased ADP values in blood may be an independent risk factor of atherosclerotic (ATS) complications.

Aim of the study: 1) Do persons with type 2 diabetes have lower ADP values than individuals without DM but with a high risk of ATS complications? 2) Do ADP values differ between persons with well controlled and persons with uncontrolled type 2 diabetes?

We examined 109 patients of the Metabolic Center of Hospital Šternberk. Out of them, 58 had type 2 diabetes, others were individuals with variously expressed risk factors of early atherosclerosis (obesity, hypertension, age, family history, smoking, dyslipidemia, etc.). In all persons under this study the following parameters were determined in peripheral venous blood: adiponectin, resistin, leptin, ObRe, cholesterol, HDL-cholesterol, triacylglycerols, glucose, HbA1c, creatinine, urea, ALT, AST, CRP, homocysteine, thrombocyte aggregation after CPG induction. The whole group was divided according to the presence of type 2DM into two subgroups; persons with diabetes were divided into the well controlled and uncontrolled subgroups. All data obtained were processed statistically using the software SPSS for Windows and Medcalc.

The adiponectin/BMI index correlated negatively with $\mathrm{HbA1c}$ value (correlation coefficient $-0.37, \mathrm{p}=0.00053$ ), triacylglycerols $(-0.4, p=0.000001)$, P-glucose $(-0.3, p=0.0017)$, uricemia $(-0.35, p=0.0007)$ and positively with HDL-cholesterol value ( $0.6, \mathrm{p}=0.00001)$. Women had higher adiponectin values than men. Persons with hypertension and with diabetes mellitus, individuals with atherogenic lipotype or persons with inflammation signs had lower values than individuals without these diseases and syndromes. Persons with wellcontrolled diabetes mellitus had higher values than persons with uncontrolled diabetes (medians of the adiponectin/BMI index 9.7 vs. $6.7, \mathrm{p}<0.01$ ).

Persons with type 2 diabetes mellitus have lower ADP values than persons with a high ATS risk without diabetes mellitus. Persons with wellcontrolled diabetes mellitus (DM) and with satisfactory compensation have significantly higher ADP levels (independently of other metabolic parameters of DM control). ADP may be a new marker of metabolic control in persons with a high risk of atherosclerotic complications.

\section{INTRODUCTION}

Adiponectin is an adipocytokin with numerous antiatherogenic properties. Its antiatherogenic effect is mediated through its binding ability to collagen and antiinflammatory influence.

The results obtained in the present study indicate that adiponectin is a direct link between obesity and coronary heart disease (CHD) origin; its anti-inflammatory effect was proved as well as its positive effect on metabolism with regard to prevention of atherogenesis ${ }^{13}$.

On the basis of several recent papers reporting on direct relation between coronary heart disease, diabetes mellitus (DM) and adiponectin we focused on the following aspects:
- Do persons with type 2DM have lower adiponectin levels than persons with a high risk of atherosclerotic complications without DM?

- Do adiponectin levels differ in type 2DM with wellcontrolled from those in uncontrolled persons with type $2 \mathrm{DM}$ ?

\section{METHODS}

We examined 109 persons, patients of the Metabolic Center of the Hospital Šternberk. Out of them, 58 were persons with type $2 \mathrm{DM}$ (7 patients ( $12 \%$ ) were treated by complementary insulin therapy, others $(78 \%)$ were individuals with variously expressed risk factors of early 
atherosclerosis (obesity, hypertension, age, family history, dyslipidemia, etc.). Individuals with creatinin over $120 \mathrm{umol} / 1$, persons with clinical signs of system inflammation and persons with type 1 DM were excluded from the study.

In all persons under study, the following parameters were determined in peripheral venous blood: adiponectin (ELISA sandwich, Biovendor), resistin (ELISA sandwich, Biovendor), leptin (ELISA sandwich, Biovendor), leptin receptor ObRe (ELISA sandwich, Biovendor), cholesterol (enzyme, BioVendor), HDL-cholesterol (direct assay, BioVendor), triacylglycerols (enzyme, BioVendor), glucose (enzyme, Lachema), HbAlc (HPLC affinitive boronate, Primus), creatinin (Jaffe), urea (enzyme, BioVendor), ALT (IFCC, BioVendor), AST (IFCC, BioVendor), CRP ultrasensitive (LEIA, DPC), blood count (Coulter), homocystein (LEIA, DPC), IGF-1 (LEIA, DPC), thrombocyte aggregation after induction by cationic propylgallate (CPG).

The whole group was divided according to the presence of type $2 \mathrm{DM}$ into two subgroups; the group of persons with diabetes mellitus was divided according to compensation level into the short-term (long-term) compensated and non-compensated individuals. The criterion of satisfactory long-term compensation in persons with DM was the concentration of fructosamine $<270 \mu \mathrm{mol} / 1$.

The individuals with ASA resistance were persons with values (aggregometry) slope after CPG induction $>53 \% / \mathrm{min}$ and/or values of spontaneous aggregability $>5 \%$.

The persons with inflammation were persons with CPR concentration $>15 \mathrm{mg} / 1$.

All data were processed by SPSS software for Windows and Medcalc. Associated quantities are expressed as mean \pm standard deviation, unless otherwise stated. Adiponectin concentrations in the groups were compared by the method of distribution analysis (ANOVA, Kruskal Wallis tests), by means of non-parametric Student t tests and ROC analysis. Adiponectin concentrations and other quantities were mutually correlated using Spearmann correlation coefficient. Category data were compared by $\chi^{2}$ test, $\mathrm{p}<0.05$ was considered to be statistically significant.

\section{RESULTS}

Adiponectin concentrations correlated negatively with BMI values (correlation coefficient $-0.34, \mathrm{p}=0.0003$ ), serum fasting glucose $(-0.35, \mathrm{p}=0.0002)$, uricaemia $(-0.32, p=0.00001)$, serum triacylglycerols $(-0.43$, $\mathrm{p}=0.000001)$, HbA1c $(-0.32, \mathrm{p}=0.02)$, and positively with serum HDL value $(-0.44, \mathrm{p}=0.000001)$.

For conversion of adiponectin to BMI value we found that the adiponectin/BMI index correlated negatively with HbA1c $(-0.37, \mathrm{p}=0.00053)$, triglycerides $(-0.4, p=0.000001)$, fasting glucose $(-0.3, p=0.0017)$, uricemia $(-0.35, \mathrm{p}=0.0007)$, and positively with HDL
$(0.6, p=0.00001)$. No significant correlations were found between adiponectin and resistin, adiponectin and leptin, and adiponectin and $\mathrm{ObRe}$.

Women had higher adiponectin values than men.

Distribution analysis showed that persons with hypertension, with diabetes mellitus, individuals with atherogenic lipotype and persons with inflammation signs had lower adiponectin values than subjects without these diseases and syndromes. Patients with satisfactory long-term compensation had higher ADP values that longterm "decompensated" individuals. The level of short-term compensation did not play a role in adiponectin values.

Patients treated with ASA ( $100 \mathrm{mg} /$ day) had significantly higher adiponectin values than individuals not treated with ASA; no differences were found between those subgroups (in contrast to persons with/without diabetes mellitus, men/women in other characteristics (Table 1).

Adiponectin values were not affected by complementary insulin therapy, oral antidiabetic drugs or their combination. No differences in adiponectin concentration were found in persons with osteoporosis, ASA resistance, smokers, individuals treated with statins, fibrates or their combination, HRT or raloxifen (Table 2).

\section{DISCUSSION}

In 1995, a report was published on adipocyte-produced protein, which is present in the serum $(30 \mathrm{kDa})$. This protein was named adiponectin, or Acrp30 (adipocyte complement-related protein of $30 \mathrm{kDa}$ ), GBP28 (gelating binding protein $28 \mathrm{kDa}$ ) or AdipoQ. Adiponectin is structurally similar to collagen and Clq (contains collagen-similar domains and C1q-like globular domain) and displays a high binding ability to collagen ${ }^{8,38}$.

This adipocytokin differs from most adipose tissueproduced proteins by decreased production in obese and insulin-resistant persons (e.g. in contrast to leptin or resistin). The most important effects of adiponectin are stimulated phosphorylation of Ac-Co-A carboxylase, stimulated oxidation of free fatty acids, stimulated metabolism of glucose and lactate, reduction of gluconeogenetic enzymes, improved effectiveness of insulin, inhibition of local growth factors, production of some cytokines, etc. In summary, adiponectin exhibits important "antidiabetic" and "antiatherogenic" effects (the term of adipovascular axis is used $)^{15}$.

Expression of adiponectin and its concentration in the blood is regulated by many substances (insulin, corticoids, catecholamines, adhesive molecules, cytokines and adipocytokines, estrogens, androgens, prolactin, IGF-1, PPAR-gamma, etc.).

First clinical studies demonstrated that lower adiponectin concentrations occur in obese individuals, patients with signs of insulin resistance (IR), type $2 \mathrm{DM}$ even in their childhood. A direct relation between adiponectin and IR was proved (hyperinsulinemic euglycemic clamp); adiponectin correlated negatively with 
BMI, relative amount of adipose tissue, triacylglycerols concentration, uricemia (even after conversion into age, sex and body fat). It is believed (if insulin resistance is considered as a key factor of diabetes mellitus pathogenesis) that adiponectin affects directly the origin and progression of type $2 \mathrm{DM}$.

Interesting enough are decreased ADP levels even in persons with type $1 \mathrm{DM}^{1,2,6,13}$.

Adiponectin concentration is under a strong genetic control. It was proved that relatives of persons with type 2 DM have decreased expression (by about $45 \%$ ) of adiponectin in adipose tissue, but normal adiponectin serum concentration. In these persons an impaired adiponectin regulation may be present ${ }^{19}$.

It seems probable that higher adiponectin concentration may predict an increased insulin sensitivity. Such correlation is independent of fat mass and probably affects directly lipoprotein concentration and insulin-mediated production of non-esterified fatty acids (NEFA) ${ }^{12,15}$.

This hypothesis is supported by the fact that glitasons (e.g. rosiglitason) protects the organism against the lipidinduced insulin resistance (particularly in the liver). This effect may be mediated by a chronic elevation of adiponectin during the therapy with glitasons (a two-week daily therapy results in adiponectin elevation by about $130-200 \%)^{12}$.

The study of the Pima Indians (population with a high type 2 DM prevalence and incidence) verified that a high adiponectin concentration is associated with a low risk of type $2 \mathrm{DM}^{2,29}$.

It was found that the atherogenic lipotype (hypertriacy lglycerolemia, enhanced ApoB, reduced HDL-cholesterol, slight elevation of LDL-cholesterol or enhanced ApoE or NEFA) is associated with reduced adiponectin concentration even in persons without diabetes mellitus. Reduction of adiponectin may probably account for the origin of metabolic syndrome ${ }^{31}$. On the contrary, a positive correlation between HDL-cholesterol (ApoAI) and adiponectin is considered as another evidence of possible use of adiponectin as an antiatherogenic marker ${ }^{2}$.

The above-mentioned findings suggested the existence of the so-called adipovascular axis. Certain adipocytokin seem to play a role even in the origin of atherosclero$\operatorname{sis}^{15}$.

Adiponectin synthesis was found to be reduced in subjects with CHD and endothelial dysfunction. Reduced adiponectin concentration is associated with CHD incidence (independently of the presence of DM, relative amount fat, BMI, dyslipoproteinemia, hypertension, smoking). The study reporting this finding indicated that men with hypoadiponectinemia have a significalty higher risk of CHD, independently of other risk factors ${ }^{3,30}$.

Adipocytes are known to produce several biologically active substances responsible for the origin of hypertension. Adiponectin appears to affect the origin of hypertension (persons with essential hypertension were found to have lower adiponectin concentrations). A negative correlation was proved between adiponectin and mean systolic and diastolic blood pressure. The above findings indicate that standardization of metabolic variations in persons with limit values of blood pressure would be desirable; adiponectin assessment may be very useful when considering a type of intervention ${ }^{5,9,32}$.

Adiponectin is accumulated mainly in the affected veins where reduces the endothelial inflammatory response, proliferation of smooth muscle cells and transformation of macrophages. Experimental studies proved that hypoadiponectinemia is associated with proliferation of smooth muscle cells of veins and excess production of growth factors (EGF, HB-EGF, BFGF) ${ }^{12}$.

In this context therapeutical approaches are speculated, namely adiponectin elevation through pharmacological or non-pharmacological intervention and thus prevent restenoses of coronary arteries ${ }^{14,28}$.

Our study confirmed recent findings that persons with diabetes mellitus have significantly lower adiponectin concetrations than persons without DM (even after adjustment to BMI) and that adiponectin concentration correlates negatively with insulin resistance markers. We also confirmed that persons with hypertension and atherogenic lipotype have reduced adiponectin concentrations in serum.

Highly interesting is the fact that adiponectin in persons with type $2 \mathrm{DM}$ correlated negatively with $\mathrm{HbA} 1 \mathrm{c}$ (independently of fructosamine concentration). The obtained results suggest that the subgroups DM/non-DM have higher differences in adiponectin concentration than in BMI. This may be due to the fact that the presence of DM is associated more with reduced production of adiponectin than a more obesity without DM. Adiponectin levels may be related to DM control and severity of dyslipidemia. Thus, adiponectin may be a new marker of metabolic control of individuals with high risk of cardiovascular complications of atherosclerosis.

This hypothesis is supported also by our next finding that persons with inflammation signs had low adiponectin concentrations. This corresponds to the findings of relations between adipocytokines and the presence of inflammation, i.e. correlations between the present inflammation and manifestation of atherosclerotic complications.

It should be pointed out that individuals treated with $100 \mathrm{mg}$ of ASA/day had lower adiponectin concentrations in serum than the ASA non-treated persons. It is supposed that ASA may influence the concentration of some inflammatory agents.

\section{CONCLUSION}

Persons with type 2DM have lower adiponectin concetrations in serum than patients with a high risk of atherosclerotic complications without DM. Individuals with satisfactory DM control have significantly higher adiponectin concentrations (irrespective of other metabolic markers of DM control). Adiponectin may be a novel marker of metabolic control of persons with a high risk of cardiovascular complications of atherosclerosis. 
Table 1. Medians of measured parameters in individual subgroups (only significant differences* are presented).

\begin{tabular}{|l|c|c|r|r|r|r|r|r|c|c|c|}
\hline Subgroups & $\mathrm{n}$ & ADP & $\begin{array}{c}\text { ADP/ } \\
\text { BMI }\end{array}$ & FPG & UA & HDL & Tg & FR & $\begin{array}{c}\text { Hb } \\
\text { A1c }\end{array}$ & Lep & Res \\
\hline Men & 57 & 3 & 8.7 & 6.4 & 357 & 1.3 & 2.1 & & & 17.0 & \\
\hline Women & 52 & 3 & 13 & 7.6 & 280 & 1.5 & 1.6 & & & 32.3 & \\
\hline Persons with DM & 58 & 2 & 8.7 & 8.4 & 338 & 1,3 & 2 & 283 & 6.8 & & \\
\hline Persons without DM & 51 & 4 & 12.9 & 5.5 & 303 & 1.5 & 1,6 & 253 & 5.5 & & \\
\hline $\begin{array}{l}\text { Long-term compensated DM } \\
\text { Long-term non-compensated DM }\end{array}$ & 30 & 3 & 9.7 & 7.0 & & 1.4 & & & & & \\
\hline $\begin{array}{l}\text { ASA therapy } \\
\text { No ASA therapy }\end{array}$ & 54 & 2 & 6.7 & 10 & & 1.1 & & & & & \\
\hline $\begin{array}{l}\text { Inflamation } \\
\text { No inflammation }\end{array}$ & 28 & 3 & 9.5 & & & & & & & & \\
\hline $\begin{array}{l}\text { Hypertension } \\
\text { Hypertension absent }\end{array}$ & 81 & 3 & 11.8 & & & & & & & & \\
\hline
\end{tabular}

* Differences of the above parameters in subgroups: $p<0.01$

$\begin{array}{llllll}\text { UA } & \text { uric acid } & \text { Res } & \text { resistin } & & \\ \text { AN } & \text { adiponectin } & \text { FR } & \text { fructosamine } & \text { Lep } & \text { leptin } \\ \text { BMI } & \text { body mass index } & \text { FPG } & \text { fasting plasma glucose } & \text { HDL } & \text { HDL-cholesterol } \\ \text { Tg } & \text { triacylglycerols } & \text { HbA1C } & \text { hemoglobin A1C } & & \end{array}$

Tg triacylglycerols

Table 2. Medians of adiponectin and the adiponectin/BMI index in some subgroups where differences* were expected and were non-significant.

\begin{tabular}{|l|c|c|c|}
\hline Subgroups & N & Adiponectin & AN/BMI \\
\hline DM-insulin therapy & 7 & 2 & 8.1 \\
DM-no insulin therapy & 51 & 2 & 8.1 \\
\hline Short-term compensated DM & 28 & 3 & 8.1 \\
Short-term non-compensated DM & 30 & 2 & 9.5 \\
\hline Osteoporosis present & 25 & 4 & 15.9 \\
Osteoporosis absent & 84 & 4 & 9.8 \\
\hline ASA resistance & 37 & 3 & 10.0 \\
ASA responder & 33 & 2 & 8.6 \\
\hline
\end{tabular}

* Differences between the above parameters in subgroups have the value $p>0.05$

ADP adiponectin

\section{ACKNOWLEDGEMENT}

This work was supported by grant MSM 151100003 from the Ministry of Youth and Education of the Czech Republic.

\section{REFERENCES}

1. Combs TP, Berg AH, Rajala MW, Klebanov S, Iyengar P, JimenezChillaron JC, Patti ME, Klein SL, Weinstein RS, Scherer PE. (2003) Sexual Differentiation, Pregnancy, Calorie Restriction, and
Aging Affect the Adipocyte-Specific Secretory Protein Adiponectin. Diabetes 52, 268-276.

2. Tschritter O, Fritsche A, Thamer C, Haap M, Shirkavand F, Rahe S, Staiger H, Maerker E, Haring H, Stumvoll M. (2003) Plasma adiponectin concentrations predict insulin sensitivity of both glucose and lipid metabolism. Diabetes 52, 239-243.

3. Kumada M, Kihara S, Sumitsuji S, Kawamoto T, Matsumoto S, Ouchi N, Arita Y, Okamoto Y, Shimomura I, Hiraoka H, Nakamura T, Funahashi T, Matsuzawa Y. (2003) Association of hypoadiponectinemia with coronary artery disease in men. Arterioscler Thromb Vasc Biol 23, 85-89.

4. Delporte ML, Brichard SM, Hermans MP, Beguin C, Lambert M (2003) Hyperadiponectinaemia in anorexia nervosa. Clin. Endocrinol. (Oxf) 58(1), 22-29. 
5. Adamczak M, Wiecek A, Funahashi T, Chudek J, Kokot F, Matsuzawa Y. (2003) Decreased plasma adiponectin concentration in patients with essential hypertension. Am J Hypertens 16, 72-75.

6. Nemet D, Wang P, Funahashi T, Matsuzawa Y, Tanaka S, Engelman L, Cooper DM. (2003) Adipocytokines, body composition, and fitness in children. Pediatr Res 53, 148-152.

7. Fain JN, Cheema PS, Bahouth SW, Lloyd Hiler M. (2003) Resistin release by human adipose tissue explants in primary culture. Biochem Biophys Res Commun 17, 674-678.

8. Ishikawa Y, Akasaka Y, Ishii T, Yoda-Murakami M, Choi-Miura NH, Tomita M, Ito K, Zhang L, Akishima Y, Ishihara M, Muramatsu M, Taniyama M. (2003) Changes in the distribution pattern of gelatin-binding protein of $28 \mathrm{kDa}$ (adiponectin) in myocardial remodelling after ischaemic injury. Histopathology 42, 43-52.

9. Viengchareun S, Zennaro MC, Pascual-Le Tallec L, Lombes M (2002) Brown adipocytes are novel sites of expression and regulation of adiponectin and resistin. FEBS Lett. 18, 345-350.

10. Motoshima H, Wu X, Sinha MK, Hardy VE, Rosato EL, Barbot DJ, Rosato FE, Goldstein BJ. (2002) Differential regulation of adiponectin secretion from cultured human omental and subcutaneous adipocytes: effects of insulin and rosiglitazone. J Clin Endocrinol Metab 87, 5662-5667.

11. Mallamaci F, Zoccali C, Cuzzola F, Tripepi G, Cutrupi S, Parlongo S, Tanaka S, Ouchi N, Kihara S, Funahashi T, Matsuzawa Y (2002) Adiponectin in essential hypertension. J Nephrol 15 , 507-511.

12. Okamoto Y, Kihara S, Ouchi N, Nishida M, Arita Y, Kumada M, Ohashi K, Sakai N, Shimomura I, Kobayashi H, Terasaka N, Inaba T, Funahashi T, Matsuzawa Y. (2002) Adiponectin reduces atherosclerosis in apolipoprotein E-deficient mice. Circulation 106, 2767-2670.

13. Ukkola O, Santaniemi M. (2002) Adiponectin: a link between excess adiposity and associated comorbidities? J Mol Med 80 696-702.

14. Yamauchi T, Kamon J, Waki H, Imai Y, Shimozawa N, Hioki K, Uchida S, Ito Y, Takakuwa K, Matsui J, Takata M, Eto K, Terauchi Y, Komeda K, Tsunoda M, Murakami K, Ohnishi Y, Naitoh T, Yamamura K, Ueyama Y, Froguel P, Kimura S, Nagai R, Kadowaki T. (2003) Globular Adiponectin Protected ob/ob Mice from Diabetes and ApoE-deficient Mice from Atherosclerosis. J Biol Chem 278, 2461-2468.

15. Yang WS, Lee WJ, Funahashi T, Tanaka S, Matsuzawa Y, Chao CL, Chen CL, Tai TY, Chuang LM. (2002) Plasma adiponectin levels in overweight and obese Asians. Obes Res 10, 1104-1110.

16. Yamamoto Y, Hirose H, Miyashita K, Nishikai K, Saito I, Taniyama M, Tomita M, Saruta T. (2002) PPAR(gamma)2 gene Pro12Ala polymorphism may influence serum level of an adipocyte-derived protein, adiponectin, in the Japanese population. Metabolism 51, 407-1409.

17. Yu S, Matsusue K, Kashireddy P, Cao WQ, Yeldandi V, Yeldandi AV, Rao MS, Gonzalez FJ, Reddy JK. (2003) Adipocyte-specific Gene Expression and Adipogenic Steatosis in the Mouse Liver Due to Peroxisome Proliferator-activated Receptor gamma 1 (PPARgamma 1) Overexpression. J Biol Chem 278, 498-505.

18. Makimura H, Mizuno TM, Bergen H, Mobbs CV. (2002) Adiponectin is stimulated by adrenalectomy in ob/ob mice and is highly correlated with resistin mRNA. Am J Physiol Endocrinol Metab 286, 1266-1271.

19. Lihn AS, Ostergard T, Nyholm B, Pedersen SB, Richelsen B, Schmitz O. (2003) Adiponectin expression in adipose tissue is reduced in first-degree relatives of type 2 diabetic patients. Am J Physiol Endocrinol Metab 284, E443-E448.

20. Stefan N, Stumvoll M. Horm (2002) Adiponectin-its role in metabolism and beyond. Metab Res 34, 469-474.

21. Stefan N, Vozarova B, Funahashi T, Matsuzawa Y, Ravussin E, Weyer C, Tataranni PA. (2002) Plasma adiponectin levels are not associated with fat oxidation in humans. Obes Res 10 , 1016-1020.

22. Yamauchi T, Kamon J, Minokoshi Y, Ito Y, Waki H, Uchida S, Yamashita S, Noda M, Kita S, Ueki K, Eto K, Akanuma Y, Froguel P, Foufelle F, Ferre P, Carling D, Kimura S, Nagai R, Kahn BB, Ka- dowaki T. (2002) Adiponectin stimulates glucose utilization and fatty-acid oxidation by activating AMP-activated protein kinase. Nat. Med. 8, 1288-1295.

23. Wagner JA. (2002) Overview of biomarkers and surrogate endpoints in drug development. Dis Markers 18, 41-46.

24. Javorschi S, Hevener AL, Kruszynska YT, Norman RA, Sinha M, Olefsky JM. (2002) The effect of thiazolidinediones on plasma adiponectin levels in normal, obese, and type 2 diabetic subjects. Diabetes 51, 2968-2974.

25. Hulver MW, Zheng D, Tanner CJ, Houmard JA, Kraus WE, Slentz CA, Sinha MK, Pories WJ, MacDonald KG, Dohm GL. (2002) Adiponectin is not altered with exercise training despite enhanced insulin action. Am J Physiol Endocrinol Metab 283, E861-865.

26. Nishizawa H, Shimomura I, Kishida K, Maeda N, Kuriyama H, Nagaretani H, Matsuda M, Kondo H, Furuyama N, Kihara S, Nakamura T, Tochino Y, Funahashi T, Matsuzawa Y. (2002) Androgens decrease plasma adiponectin, an insulin-sensitizing adipocyte-derived protein. Diabetes 51, 2734-2741.

27. Matsubara M, Maruoka S, Katayose S. (2002) Inverse relationship between plasma adiponectin and leptin concentrations in normalweight and obese women. Eur J Endocrinol 147, 173-180.

28. Matsuda M, Shimomura I, Sata M, Arita Y, Nishida M, Maeda N, Kumada M, Okamoto Y, Nagaretani H, Nishizawa H, Kishida K, Komuro R, Ouchi N, Kihara S, Nagai R, Funahashi T, Matsuzawa Y. (2002) Role of adiponectin in preventing vascular stenosis. The missing link of adipo-vascular axis. J Biol Chem 277, 37487-37491.

29. Lindsay RS, Funahashi T, Hanson RL, Matsuzawa Y, Tanaka S, Tataranni PA, Knowler WC, Krakoff J. (2002) Adiponectin and development of type 2 diabetes in the Pima Indian population. Lancet 360, 57-58.

30. Kondo H, Shimomura I, Matsukawa Y, Kumada M, Takahashi M, Matsuda M, Ouchi N, Kihara S, Kawamoto T, Sumitsuji S, Funahashi T, Matsuzawa Y. (2002) Association of adiponectin mutation with type 2 diabetes: a candidate gene for the insulin resistance syndrome. Diabetes 51, 2325-2328.

31. Matsubara M, Maruoka S, Katayose S (2002) Decreased plasma adiponectin concentrations in women with dyslipidemia. J Clin Endocrinol Metab 87, 2764-2769.

32. Kazumi T, Kawaguchi A, Sakai K, Hirano T, Yoshino G. (2002) Young men with high-normal blood pressure have lower serum adiponectin, smaller LDL size, and higher elevated heart rate than those with optimal blood pressure. Diabetes Care 25, 971-976.

33. Shimada K, Miyauchi K, Mokuno H, Miyazaki T, Seki E, Watanabe Y, Iwama Y, Shigekiyo M, Matsumoto M, Okazaki S, Tanimoto K, Kawamura M, Suzuki H, Kurata T, Sato H, Daida H. (2002) Predictive value of the adipocyte-derived plasma protein adiponectin for restenosis after elective coronary stenting. Jpn Heart J 43, 85-91.

34. Ouchi N, Kihara S, Arita Y, Nishida M, Matsuyama A, Okamoto Y, Ishigami M, Kuriyama $\mathrm{H}$, Kishida K, Nishizawa $\mathrm{H}$, Hotta $\mathrm{K}$, Muraguchi M, Ohmoto Y, Yamashita S, Funahashi T, Matsuzawa Y. (2001) Adipocyte-derived plasma protein, adiponectin, suppresses lipid accumulation and class A scavenger receptor expression in human monocyte-derived macrophages. Circulation 103, 1057-1063.

35. Ouchi N, Kihara S, Arita Y, Okamoto Y, Maeda K, Kuriyama H, Hotta K, Nishida M, Takahashi M, Muraguchi M, Ohmoto Y, Nakamura T, Yamashita S, Funahashi T, Matsuzawa Y. (2000) Adiponectin, an adipocyte-derived plasma protein, inhibits endothelial NF-kappaB signaling through a cAMP-dependent pathway. Circulation 102, 1296-1301.

36. Yokota T, Oritani K, Takahashi I, Ishikawa J, Matsuyama A, Ouchi N, Kihara S, Funahashi T, Tenner AJ, Tomiyama Y, Matsuzawa Y. (2000) Adiponectin, a new member of the family of soluble defense collagens, negatively regulates the growth of myelomonocytic progenitors and the functions of macrophages. Blood 96, 1723-1732.

37. Hotta K, Funahashi T, Arita Y, Takahashi M, Matsuda M, Okamoto $\mathrm{Y}$, Iwahashi H, Kuriyama H, Ouchi N, Maeda K, Nishida M, Kihara S, Sakai N, Nakajima T, Hasegawa K, Muraguchi M, Ohmo- 
to Y, Nakamura T, Yamashita S, Hanafusa T, Matsu. (2000) Plasma concentrations of a novel, adipose-specific protein, adiponectin, in type 2 diabetic patients. Arterioscler. Thromb. Vasc. Biol. 20, 1595-1599.
38. Scherer PE, Williams S, Fogliano M, Baldini G, Lodish HF. (1995) A novel serum protein similar to $\mathrm{C} 1 \mathrm{q}$, produced exclusively in adipocytes. J Biol Chem 270, 26746-26749.

39. Kojima S, Funahashi T, Sakamoto T. (2003) The variation of plasma concentrations a novel adipocyty derived protein, adiponektin, in patiens with acute myocardial infarction. Heart 89, 377-381. 